\title{
DIREITO DE EQUIDADE E DIREITO DE NECESSIDADE EM KANT
}

\author{
Mateus Salvadori ${ }^{1}$ \\ Universidade Caxias do Sul (UCS) \\ (i) https://orcid.org/0000-0002-9445-6206
}

\section{RESUMO:}

O escopo deste artigo é apresentar a Doutrina do Direito de Kant, demonstrando os problemas que o formalismo gera. Será visto que o critério de justiça kantiano (imperativo categórico do direito) é a coexistência de liberdades com leis universais e que a injustiça caracteriza-se quando isso for impedido. Kant propõe princípios metafísicos ao direito, buscando assim realizar uma fundamentação moral do jurídico. Ele distingue as leis éticas das leis jurídicas e estabelece um fundamento comum para ambas: as leis morais. Assim, o direito possui uma fundamentação moral. Todavia, isso é ignorado quando Kant trata do direito de necessidade e do direito de equidade. Segundo o autor, a coerção é necessária para o direito. Porém, há dois casos em que isso não ocorre: no direito de equidade (direito sem coerção) e no direito de necessidade (coerção sem direito). Por que Kant não resolve o problema desses dois direitos a partir da fundamentação metafísica do direito? É possível uma teoria da justiça estritamente formal, nos moldes kantianos? O presente artigo defende que uma teoria da justiça formal é insuficiente.

PALAVRAS-CHAVE: Direito de equidade; Direito de necessidade; Kant; justiça; liberdade.

\section{LAW OF EQUITY AND OF THE LAW OF NECESSITY IN KANT}

\begin{abstract}
:
The scope of this paper is to present the doctrine of law of Kant, showing the problems that formalism generates. It will be seen that the criterion of Kantian justice (categorical imperative of law) is the coexistence of liberties with universal laws and that injustice is characterized when this is prevented. Kant proposes metaphysical principles to the right, thus seeking

\footnotetext{
${ }^{1}$ Mestre e doutor em Filosofia pela Pontifícia Universidade Católica do Rio Grande do Sul (PUCRS), Rio Grande do Sul - Brasil. Professor de Filosofia na Universidade Caxias do Sul (UCS), Rio Grande do Sul - Brasil. E-mail:eletrônico: mateusche@ yahoo.com.br.
} 
to hold a moral foundation of the legal. He distinguishes the ethical laws of legal laws and establishes a common foundation for both: the moral laws. The right has a moral foundation. However, this is ignored when Kant deals with the right of need and the right to equality. According to the author, coercion is necessary for the law. However, there are two cases where this does not occur: the right to equity (without coercion right) and the right of necessity (coercion without the right). Why Kant does not solve the problem of these two rights from the metaphysical foundation of law? A theory of strictly formal justice is possible, in the Kantian manner? The article argues that a formal theory of justice is inadequate.

KEYWORDS: Law of equity; law of necessity; Kant; justice; freedom.

\section{Arbítrio, desejo e faculdade de desejar inferior e superior}

O direito, segundo Kant, caracteriza-se por ser uma relação de arbítrios e por referir-se apenas à forma e não à matéria do arbítrio. A faculdade de desejar, que se refere à matéria, é considerada inferior e a faculdade que lida com as leis puramente formais é considerada superior.

A relação jurídica não é uma relação entre arbítrios e desejos ou entre dois desejos, mas entre dois arbítrios. Portanto, a relação jurídica não se refere a desejos. Desejo é a mera expressão da vontade e indica uma finalidade que o sujeito quer alcançar; é o apetite (inclinação, tendência), a determinação espontânea da força própria de um sujeito, que acontece por meio da representação de uma coisa futura considerada como efeito da forma mesma; é apetite habitual de natureza sensível (cf. Anthr., § 73)². Já o arbítrio é a consciência da capacidade de atingir e realizar o desejo ou o fim proposto. O direito somente é possível quando há dois arbítrios, ou seja, quando há duas capacidades autônomas que tem a possibilidade de deliberar e alcançar os seus desejos, a partir de uma relação recíproca.

Por exemplo, para a possibilidade de um contrato de compra e venda "não é suficiente que o arbítrio do comprador se encontre com o desejo do vendedor, mas é preciso que também por parte do vendedor o desejo se resolva em arbítrio" (BOBBIO, 1991, p. 69). Somente se há dois arbítrios é possível classificar a relação como jurídica. Outro exemplo é em relação a um mendigo. Pode-se dizer que ele tem desejo de receber esmola, mas jamais arbítrio para tal. E sobre o mero desejo não é possível existir uma relação jurídica.

Desta forma, para que haja uma relação jurídica é necessário reciprocidade (de arbítrio); assim, na relação jurídica, não é levado em consideração a matéria do arbítrio, isto é, o fim que cada sujeito se propõe

\footnotetext{
${ }^{2}$ As abreviações de algumas das obras citadas neste artigo são as seguintes: Crítica da Razão Prática (KpV), A Metafísica dos Costumes (MS), Antropologia (Anthr.). As obras citadas serão as traduções indicadas nas referências.
} 
com o objeto que quer alcançar, mas somente é levada em consideração a forma. Não se pergunta se alguém leva vantagens ou não com a mercadoria que está comprando, mas pergunta-se apenas sobre a forma da relação do arbítrio recíproco; conforme já foi visto, em um contrato de compra e venda, não importam as relações subjetivas dos contratantes, mas importam apenas as condições externas, isto é, as condições formais que legitimam um contrato. As vantagens ou desvantagens em um contrato de compra e venda não são consideradas pelo direito; somente são relevantes as condições formais do contrato.

$\mathrm{O}$ direito não trata da intenção do sujeito agente. Ele refere-se apenas a ações externas e à sua conformidade à lei. Quando há a regulação do direito acerca da instituição do casamento, por exemplo, o direito não se questiona sobre com quem se deve casar ou sobre os fins individuais almejados através desta instituição; ele "limita-se a fixar as modalidades por meio das quais torna-se a atuação das minhas intenções" (BOBBIO, 1991, p. 69-70). Portanto,

O direito é a forma universal de coexistência dos arbítrios [...]. Enquanto tal é a condição ou o conjunto das condições segundo as quais os homens podem conviver entre si, ou o limite da liberdade de cada um, de maneira de que todas as liberdades externas possam coexistir segundo uma lei universal. [...] $\mathrm{O}$ direito é o que possibilita a livre coexistência dos homens, a coexistência em nome da liberdade, porque somente onde a liberdade é limitada, a liberdade de um não se transforma numa não-liberdade para os outros, e cada um pode usufruir da liberdade que lhe é concedida pelo direito de todos os outros de usufruir de uma liberdade igual à dele (BOBBIO, 1991, p. 71).

Dessa concepção formal acerca do conceito do direito surge o positivismo jurídico, representado por pensadores como Kelsen, Del Vecchio, Stammler e outros. O juspositivismo não trata o direito em um sentido prescritivo, mas apenas descritivo e defende um conceito de validade meramente formal.

Já em relação à faculdade de desejar, Kant distingue duas formas de faculdade: a inferior e a superior. A faculdade de desejar inferior refere-se aos sentimentos, às paixões; a faculdade que lida com regras práticas materiais, a saber, os sentimentos, os desejos (apetite) é uma faculdade inferior, pois pressupõe sempre como seu motivo determinado um objeto empírico. A faculdade de desejar superior refere-se às leis puramente formais. É determinada pela simples representação da lei.

Justificar uma lei é mostrar qual é o princípio que a fundamenta. $\mathrm{O}$ princípio último se põe por si mesmo. Esse princípio último não pode ser material; ele só pode ser e é um princípio formal. Não há como explicitar o princípio material como, por exemplo, a felicidade pessoal, a não ser 
apelando-se para a experiência. O problema da experiência é que ela é particular e contingente e o princípio precisa ser universal. Conforme Kant,

Todas as regras práticas materiais põem o fundamento determinante da vontade na faculdade de apetição inferior e, se não houvesse nenhuma lei meramente formal da vontade, que a determinasse suficientemente, não poderia tampouco ser admitida uma faculdade de apetição superior $(\mathrm{KpV}, 2011$, p. $38)$.

A vontade é determinada ou pela matéria ou pela forma. Eliminando a matéria, resta apenas a forma. A razão é uma faculdade de desejar superior. A faculdade de desejar inferior está sujeita a faculdade de desejar superior. Kant não afirma que uma lei não tem matéria, pois toda lei tem forma e matéria, mas a matéria não deve determinar a vontade para que a ação tenha valor moral.

Kant não nega a existência das consequências de uma ação, porém não é a expectativa das consequências que determina a vontade para que ela seja universalizável. Os princípios práticos materiais não servem para serem os princípios supremos da moralidade e da legalidade. No momento em que se introduz conteúdo empírico através de mediações sociais ou através de um princípio prático material, o apriorismo cai. Para Kant, o empírico não pode determinar a criação das leis. Se determinasse, haveria um número enorme de possíveis determinações de vontade. Desta forma, Kant busca um modelo único, uma ideia reguladora. As leis práticas têm conteúdo e circunstância, pois é próprio da lei delimitar e definir um conteúdo determinado. Todavia, o princípio que serve de ideia reguladora deve ser $a$ priori. No teorema III da Crítica da Razão Prática, Kant diz:

A matéria de um princípio prático é o objeto da vontade. Este objeto ou é o fundamento determinante da vontade, ou não o é. Se ele é o fundamento determinante da mesma, então a regra da vontade estaria submetida a uma condição empírica (à relação da representação determinante com o sentimento de prazer e desprazer), consequentemente não seria nenhuma lei prática. Ora, se se separa de uma lei toda a matéria, isto é, todo objeto da vontade (enquanto fundamento determinante), dela não resta senão a simples forma de uma legislação universal. Logo, um ente racional ou não pode absolutamente representar seus princípios prático-subjetivos, isto é, suas máximas, ao mesmo tempo como leis universais, ou tem de admitir que a simples forma dos mesmos, segundo a qual eles convêm à legislação universal, torna-os por si só uma lei prática (KpV, 2011, p. 45).

Separando a matéria da forma, se retira tudo aquilo de empírico que possa motivar a ação. Sobra, assim, apenas a forma da lei, isto é, a sua universalidade. Já para Hegel não tem como separar forma e matéria, pois a 
concretização do princípio formal é uma exigência de sua determinação. Não é possível eliminar a matéria da lei, pois a mesma é constitutiva do princípio.

A prova disso se encontra nas mediações sociais. A mediação social da vontade livre cria leis a partir de costumes, hábitos e tradições. Não dando uma base material ao princípio, ele fica vazio, permanecendo uma indeterminação. Consequência disso, o critério da não-contradição não se põe. Não existe contradição formal. A contradição somente se põe quando se fere uma determinação ou um princípio que diz o que deve ser feito. A dicotomia forma-conteúdo só é possível pela permanência no vazio formalismo. Esse vazio formalismo afeta a construção do imperativo categórico. Segundo Rawls,

é importante reconhecer que a lei moral, o imperativo categórico e o procedimento do IC são três coisas distintas. A lei moral é uma ideia da razão. Determina um princípio que se aplica a todos os seres razoáveis e racionais (ou seres razoáveis, para abreviar) sejam ou não, como nós, seres finitos imbuídos de necessidades. Emprega-se para Deus, para os anjos e para os seres razoáveis presentes em outras partes do universo (se existirem), assim como para nós. O imperativo categórico, sendo um imperativo, dirige-se apenas àqueles seres razoáveis que, por serem finitos e imbuídos de necessidades, experimentam a lei moral como uma restrição. $\mathrm{Na}$ qualidade de seres assim definidos, experimentamos a lei moral dessa maneira e, assim, o imperativo categórico especifica como essa lei deve aplicar-se a nós [...]. Para que o imperativo categórico se aplica à nossa situação, precisa adaptar-se às nossas circunstâncias na ordem da natureza. Essa adaptação é realizada pelo procedimento do IC, na medida em que leva em conta as condições normais da vida humana por meio da formulação da lei da natureza [...] (2005, p. 192-3).

Conforme Weber, "a não contradição entre uma máxima e a lei universal é o critério de moralidade adotado por Kant na Filosofia prática" (2009, p. 91). Contradição em Kant ocorre, portanto, quando o agente deseja que o princípio seja válido para todos, porém querendo, ao mesmo tempo, que haja uma exceção em favor a si mesmo. Assim, querer que a máxima continue valendo como lei universal, mas querer que haja uma exceção para si é cair em uma contradição, segundo Kant. Explicitando o significado de máxima, Höffe destaca o seguinte:

Por máxima Kant entende proposições fundamentais subjetivas do agir [...], que contêm uma determinação universal da vontade e dependem de diversas regras práticas [...]. (1) Como proposições fundamentais subjetivas, elas são diversas de indivíduo a indivíduo. (2) Como determinações da vontade, elas não designam esquemas de ordem, que um observador objetivo atribui ao agente; trata-se de princípios que o ator 


\begin{abstract}
mesmo reconhece como seus. (3) Como proposições fundamentais de que dependem diversas regras, as máximas contêm a maneira pela qual as pessoas conduzem o todo de sua vida em relação a determinados aspectos fundamentais da vida e da convivência, como, por exemplo, a indigência, o tédio da vida ou as ofensas (2005, p. 203).
\end{abstract}

Leis procedem da vontade; não se pode classificar a vontade como livre ou não livre, pois a vontade refere-se apenas à produção de leis e não à ações. Já as máximas procedem de escolhas, do arbítrio. A partir dos diversos princípios subjetivos (máximas), Kant distingue as máximas morais das máximas não-morais e, a partir do critério da universalização, indica que se deve seguir apenas as máximas morais. Na Fundamentação da Metafísica dos Costumes, Kant trata de quatro exemplos a fim de apresentar o procedimento da universalização. Ei-los:

I) um homem, por passar por uma série de males, se encontra em desespero. Estando de posse de sua razão, ele questiona-se se tirar a própria vida seria uma violação do dever para consigo mesmo. Será que, em casos extremos, a dor pode justificar o suicídio?

II) é ético em uma situação totalmente excepcional (por exemplo, graves necessidades financeiras) não cumprir a palavra dada? $\mathrm{O}$ ato de mentir e de fazer falsas promessas constituem ações imorais, pois suas máximas não podem ser queridas como leis universais. A pureza da intenção, no cumprimento do dever, é a condição de uma vontade boa em si, cujo valor é superior a tudo aquilo que a inclinação louva. $\mathrm{O}$ valor moral de uma ação consiste no respeito à lei prática pelo puro dever de cumpri-la, sem ser movido por inclinação alguma. Assim, o dever contém em si a boa vontade;

III) um homem talentoso prefere ficar no ócio, entregando-se ao prazer e não esforçar-se a fim de ampliar o seu talento. É justificável não desenvolver os próprios talentos para se dedicar apenas ao ócio? O imperativo categórico impõe a todos os indivíduos não pecar por omissão, ou seja, deve-se sim desenvolver da melhor forma possível seus talentos. Sem isso, a civilização acabaria retrocedendo;

IV) um homem, bem sucedido, vendo que outros homens estão em dificuldade prefere não ajudá-los nas suas necessidades. Isso seria justificável? É eticamente lícita uma atitude de indiferença em relação aos outros? A generalização do comportamento egoísta pode tornar-se prejuízo para o próprio egoísta. Portanto, esse comportamento não pode ser universalizado.

O primeiro e o segundo exemplo ("suicídio" e "falsa promessa", respectivamente) mostram que se eles se convertessem em leis universais, cairiam em contradição consigo mesmo. Fazer uma falsa promessa é em si mesmo contraditório, pois assim as promessas desapareceriam. Esses dois 
exemplos tratam de "deveres perfeitos ou estritos". Esses deveres, em hipótese alguma (nem no pensar e nem no querer), admitem exceções.

Sobre o terceiro e o quarto exemplo ("não desenvolver os próprios talentos" e "ser indiferente em relação aos outros", respectivamente),

não se pode querer que a máxima se transforme em lei universal da natureza, embora seja possível a subsistência de uma lei universal de acordo com tais máximas. É possível que possa subsistir uma lei, segundo a qual os que vivem na riqueza não ajudem os mais necessitados, mas não se pode querer que seja assim. Não se pode querer que as pessoas não desenvolvam seus talentos naturais, embora possa subsistir uma lei segundo a qual ninguém desenvolva seus talentos (WEBER, 2009, p. 93).

O terceiro e o quarto exemplo tratam de "deveres imperfeitos ou amplos". Esses deveres podem ser pensados, diferentemente dos deveres perfeitos (que não podem ser pensados), mas não devem ser almejados (querer). Kant aborda também o exemplo do depósito. Ei-lo:

Sem instrução o entendimento comum pode distinguir qual forma na máxima presta-se, e qual não, a uma legislação universal. Por exemplo, adotei como máxima aumentar minha fortuna através de todos os meios seguros. Agora se encontra em minhas mãos um depósito, cujo proprietário faleceu e não deixou nenhuma manifestação escrita a respeito. Naturalmente este é o caso de minha máxima. Quero saber agora somente se aquela máxima pode valer também como lei prática universal. Aplico-a, pois, ao caso presente e pergunto se ela poderia admitir a forma de uma lei, por conseguinte, se eu mediante minha máxima poderia fornecer ao mesmo tempo uma tal lei: que seja permitido a qualquer um negar um depósito, cujo assentamento ninguém pode provar-lhe. Dou-me conta imediatamente de que um tal princípio enquanto lei destruir-seia a si mesmo, porque faria com que não existisse absolutamente depósito algum. Uma lei prática, que eu reconheça como tal, tem que qualificar-se a uma legislação universal; esta é uma proposição idêntica e, pois, por si clara. Ora, se digo: minha vontade está sob uma lei prática, então não posso apresentar minha inclinação (por exemplo, no presente caso, minha cobiça) como o fundamento determinante de minha vontade apto a uma lei prática universal; pois essa inclinação, completamente equivocada no sentido de que devesse prestar-se a uma legislação universal, tem que, muito antes, sob a forma de uma legislação universal, destruir-se a si mesma (KpV, 2011, p. 45-6).

A máxima de negar o depósito se destrói a si mesma fazendo, assim, que não houvesse mais depósitos. Deve-se ter um princípio a partir do qual se pode justificar ou não justificar as leis. A razão é a faculdade de 
justificação das regras mediante princípios. Não se satisfaz apenas seguindo regras, mas quer uma justificação das regras. A forma da lei se impõe por si mesma devido a sua universalidade e não pelas possíveis exceções ou conteúdos materiais.

Kant não aceita a felicidade como princípio prático material, defendida por Aristóteles e outros. O princípio não poderia enunciar conteúdos materiais. Tudo isso, segundo Hegel, é insuficiente. O objetivo central em Kant é a busca do princípio (critério) supremo de moralidade e da justiça. O procedimento jamais será injusto; já as regras podem sim serem injustas. Não se justifica o valor moral de uma ação através de um conteúdo material.

Hegel, discordando de Kant, afirma que se nada for determinado não pode haver contradição, ou seja, na indeterminação não há contradição, mesmo nos exemplos dos deveres perfeitos, como o fim do depósito ou da falsa promessa, pois pode existir uma sociedade em que não haja propriedade privada e, portanto, depósito. Contradição em Kant é querer que um princípio seja universal (válido para todos), mas querer ao mesmo tempo abrir uma exceção a seu favor. Para Hegel, somente é possível falar em contradição se há conteúdo moral, ou seja, se há determinação de um conteúdo. A contradição em Kant trata apenas da forma; em Hegel, trata da forma e do conteúdo. Sem o princípio que diz que "devemos respeitar a propriedade privada", por exemplo, não é possível, segundo Hegel, afirmar que "negar o depósito" constitui uma contradição. Além da forma, esse princípio trata também de um conteúdo determinado e, portanto, pode-se defender que o desrespeito de um conteúdo constituído significa cair em contradição.

\section{Direito de equidade e direito de necessidade}

O direito busca, na metafísica, princípios de fundamentação que são dados pela razão (direito natural) e não pelo direito positivo. Assim, o direito positivo busca seus princípios na razão, no direito natural. As leis morais abarcam tanto as leis jurídicas como as leis éticas. Portanto, o fundamento dessas últimas leis (jurídicas e éticas) é comum. Há, assim, uma fundamentação moral para o direito. No "Apêndice à Introdução à Doutrina do Direito", Kant distingue o direito em sentido estrito e o direito no sentido lato.

Uma competência para exercer coerção está relacionada a qualquer direito em sentido restrito (ius strictum). Mas as pessoas pensam também em um direito num sentido mais lato (ius latium), no qual nenhuma lei existe pela qual uma competência de exercer coerção pudesse ser determinada. Destes verdadeiros ou pretensos direitos há dois: a equidade e o direito de necessidade (MS, 2008, p. 79-80). 
Ao propor princípios metafísicos para o direito, Kant está almejando uma doutrina moral do direito, uma fundamentação racional da doutrina do direito. Contudo, surgem dois problemas (a partir da fundamentação metafísica): i) como explicitar uma fundamentação moral do direito? ii) por que Kant não resolve o problema do direito da equidade e do direito da necessidade a partir dessa fundamentação?

O direito não é determinado por elementos empíricos, mas pela razão e, por isso, o direito é racional. Obedecer às leis jurídicas não caracteriza uma ação apenas como heterônoma. Obedecer ao direito significa seguir a razão na sua aplicação jurídica e isso possibilita a convivência entre os homens. A lei jurídica, além de ser retrospectiva (corrige os erros passados) é também prospectiva (visa antecipar os comportamentos injuriosos). A lei pública, por exemplo, que tem por objetivo garantir a coexistência pacífica entre os homens na sociedade, testa a prospectividade da lei jurídica (cf. WEINRIB, 1992, p. 36).

Há duas formas de direito: direito no sentido estrito e direito no sentido lato. $\mathrm{O}$ direito no sentido estrito é aquele que não está vinculado com o justo (Kelsen, a partir disso, vai construir uma doutrina pura do direito), mas está ligado apenas com a coerção do agir. Para Kant, a coerção é indispensável para o direito. O Estado, através do direito, obriga a todos a seguirem as leis; caso contrário, ele está autorizado para coagir. O Estado tem como objetivo garantir os direitos fundamentais, a saber, a liberdade, a igualdade, a propriedade, etc.

Para a convivência pacífica entre os homens, é necessário um senhor. No Estado de Natureza não havia esse senhor que intermediava as disputas. "Todo homem tem tanto direito quanto poder, em outras palavras, cada um tem o direito de fazer o que está em seu poder de fazer" (BOBBIO, 1987, p. 68). O Estado Civil, portanto, é necessário. O Estado de Natureza em Kant não é histórico, mas lógico. Já o contrato social é "visto como a soma consensual de declarações voluntárias, espontâneas, não intimadas, por isso mesmo vinculantes" (HECK, 2004, p. 79). O contrato que fundamenta a passagem ao estado civil não é um ato de renúncia aos direitos individuais, mas o reconhecimento de um dever e da condição da liberdade. O sujeito do contrato não é um homem empírico, mas numênico, pelo qual o Estado não é uma mera garantia dos interesses particulares, mas a unidade moral da humanidade.

Somente através da instauração do Estado podem-se garantir os direitos das pessoas. O contrato está na ordem do dever ser. Isso significa que ele serve como princípio regulador das normas jurídicas. Conforme Scruton, ele "é um teste para a justiça de um sistema legal e não para a justiça de uma distribuição de bens" (1992, p. 213). A saída do estado de natureza é uma obrigação racional a priori. Segundo Bobbio, "dizer-se que o Estado devia contentar-se com a adesão exterior, significa dizer que o Estado não devia intrometer-se em questões de consciência, e portanto devia 
reconhecer para o indivíduo um âmbito da própria personalidade" (1991, p. $57)$.

Portanto, o Estado tem limites: ele pode controlar os fatos externos, mas não os internos (dos indivíduos). O objetivo do Estado é garantir a liberdade externa de seus cidadãos. O homem, sendo um ser insociável, necessita da coerção externa estatal para viver de forma pacífica e cooperativa. Conforme Weber, "[...] é a própria razão que autoriza outro móbil (externo) para fazer cumprir as obrigações decorrentes da legislação moral. Isso é autonomia. Os que se submetem às leis são os mesmos que participam de sua elaboração" (2013, p. 40).

Já o direito no sentido lato não tem a coerção como característica essencial. Portanto, direito no sentido estrito tem como "objeto somente o que é externo nas ações" (MS, 2008, p. 78), "e é aquele que não está combinado com nada ético" (MS, 2008, p. 78). Assim, o devedor deve quitar suas dívidas devido uma obrigação (coerção) meramente externa e não por causa do dever de respeitar as leis. Não há nada de ético no direito no sentido estrito. Kant destaca duas situações em que não há uma relação necessária entre coerção ${ }^{3}$ e direito: a equidade (direito sem coerção) e o estado de necessidade (coerção sem direito).

Além do direito estar vinculado com a liberdade, a noção de coerção também possui um nexo necessário para com ele. Portanto, dois conceitos vinculados à esfera jurídica são a liberdade e a coerção.

A resistência que frustra o impedimento de um efeito promove este efeito e é conforme ele. Ora, tudo que é injusto é um obstáculo à liberdade de acordo com leis universais. Mas a coerção é um obstáculo ou resistência à liberdade. Consequentemente, se um certo uso da liberdade é ele próprio um obstáculo à liberdade de acordo com leis universais (isto é, é injusto), a coerção que a isso se opõe (como um impedimento de um obstáculo à liberdade) é conforme à liberdade de acordo com leis universais (isto é, é justa). Portanto, ligado ao direito pelo princípio de contradição há uma competência de exercer coerção sobre alguém que o viola (MS, 2008, p. 77-8).

\footnotetext{
3 "Na esfera jurídica, coação e coerção são palavras usadas sempre como sinônimas. [...] O que em Direito tornou-se necessário foi eleger os termos que marcassem a diferença entre o momento presente e o momento futuro do emprego da força, a saber, entre a coação em ato e a coação em potência. Encaminhou-se a doutrina no sentido de identificar essas situações através dos conceitos de coação (ato de coagir, situado no domínio do ser) e coatividade (possibilidade de coagir, projetada para o domínio do dever-ser). Assim, enquanto a coação configurar-se-ia no ato de restauração do direito já violado, a coatividade restringir-se-ia a evidenciar a possibilidade de tal violação. Foi precisamente a partir dessa segunda posição que Kant formulou seu histórico conceito de Direito" (VASCONCELOS in TRAVESSONI, 2011, p. 44).
} 
Kant exemplifica o direito no sentido lato a partir de dois exemplos: direito de equidade e direito de necessidade. A equidade ${ }^{4}$ (aequitas) assume

${ }^{4}$ A "tese da independência" (Unabhängigkeitsthese) entre direito e ética de Kant tem problemas, pois não está coerente com a "Doutrina do Direito" de Kant. Primeiro, porque "demonstrando que o conceito de direito [...] e a característica de coerção dele advinda não são compatíveis com o seu conceito de equidade, de modo que a equidade como direito seria uma espécie de direito que não é direito; segundo, demonstrando que, lançando mão dos fundamentos kantianos para demonstrar a diferença entre direito e ética, a equidade mais se assemelha à ética, de modo que a equidade como direito, nessa perspectiva, também seria uma espécie de direito que não é direito; terceiro, procurou-se apontar as falhas dos argumentos da 'tese da independência', uma vez que o filósofo, ao dizer sua classificação da equidade, desdiz sua explicação da equidade, e mostra o espaço nobre da equidade dentro do seu sistema jurídico como um direito que é mais do que um direito (WEBER; HAEBERLIN, 2012, p. 135). O jurídico e o ético possuem a mesma fundamentação, a saber, as leis morais. Enquanto o direito refere-se a uma ação externa, a ética refere-se a uma ação interna. "Nesse prisma, na ação cujo juízo não transcende o lícito ou ilícito para tocar no bem ou mal, a externalidade, per se, é suficiente para aferir a conformidade entre ação e lei, sendo essa lei jurídica. Como exemplo, poderíamos citar uma legislação que dispusesse sobre a aquisição originária da propriedade, por usucapião, pela posse do imóvel por um período de 15 anos. O critério apenas cronológico estabelecido nessa legislação daria conta de uma legislação jurídica, ou seja, onde o elemento externo (posse por 15 anos) seria suficiente para a aquisição da propriedade. Do contrário, quando o juízo de bem ou mal importa à ação, o seu elemento externo deve vir acompanhado da aferição do móbil interno e, como a conformidade entre ação e lei demanda a questão do princípio de determinação da vontade, essa seria uma lei ética. É a hipótese, para usar a mesma linha exemplificativa, de a legislação estabelecer, além do critério cronológico, que a posse do imóvel para o usucapião fosse de boa-fé. Nesse caso, além do elemento externo (período de tempo), seria necessária a perquirição do princípio de determinação que levou o agente à posse (se de boa ou má-fé)" (WEBER; HAEBERLIN, 2012, p. 129-30). Outro ponto a ser destacado para diferenciar direito e ética é sobre a intenção do agente, ou seja, se houve uma ação praticada por dever ou por inclinação (conforme o dever). A ética caracteriza-se pela ação praticada por dever. Já o direito é a ação praticada em conformidade ao dever. Analisando a equidade a partir da "tese da independência", pode-se dizer que a equidade - em relação ao âmbito interno e ao âmbito externo - está no âmbito interno, pois, conforme Kant, não é possível remediar este mal pelo direito, pela via judicial. Portanto, a equidade é assunto do tribunal da consciência e não do direito civil. Em relação ao dever, a equidade também se aproxima da ética, pois ao buscar praticar a equidade, se busca a justiça em si e não a um benefício qualquer. Portanto, "a equidade mostra-se um direito que não é direito" (WEBER; HAEBERLIN, 2012, p. 131). A "tese da independência" tem problemas. Busca-se solucioná-los através de uma visão acerca do direito que é mais do que um mero direito. O direito caracteriza-se pela faculdade de obrigar. Portanto, o direito não tem relação com a ética, pois ela não possui como característica essa faculdade. Um "problema da 'tese da independência' está na afirmação de que as leis jurídicas situam-se apenas no plano externo da ação, enquanto as leis éticas estão no móbil interno da ação. No tocante à ética, pode-se dizer que a dificuldade de Kant em reconhecer a presença de elemento externo na ética tem explicação no formalismo, o qual não lhe permite (como aparecerá em Hegel) uma ética da responsabilidade. Já no que se refere à tentativa kantiana de relegar o direito à externalidade, impera lembrar que ao direito, por diversas vezes, importa - e muito - o âmbito interno. Isso ocorre tanto na responsabilidade civil, em que a ação ou omissão voluntária ensejará reparação, como na responsabilidade penal, em que se procura o 
um "direito sem coerção" (Recht ohne Zwang) (MS, 2008, p. 80), ou seja, há um direito, mas não há mecanismos para exigir a efetivação desse direito. Alguém que exige a aplicação deste direito "não possui as condições necessárias a um juiz para determinar em quanto ou de que maneira sua reinvindicação poderia ser satisfeita" (MS, 2008, p. 80). Por exemplo:

Supõe que os termos nos quais uma companhia comercial foi formada foram que os sócios deveriam dividir igualmente os lucros, mas que um sócio, entretanto, fez mais do que os outros e assim perdeu mais quando a companhia se defrontou com reveses. Por meio da equidade ele pode exigir mais da companhia do que apenas uma partilha igual justamente com os outros (MS, 2008, p. 80).

Todo aquele que investe mais em uma empresa deveria receber mais se houvesse grandes perdas. Isso é assegurado pela equidade. Todavia, segundo o direito no sentido estrito, a exigência do cumprimento da equidade seria recusada, pois o juiz não teria dados suficientes para decidir acerca do contrato firmado. "Ou supõe que um servo doméstico recebeu seus salários, no fim de um ano, em dinheiro que sofreu depreciação no intervalo, de modo que não pode comprar com ele o que poderia ter comprado com ele quando concluiu o contrato" (MS, 2008, p. 80).

chamado elemento subjetivo do tipo, é dizer, o caráter volitivo da conduta para a qual uma sanção é prevista. Em ambos os casos, perquirir-se-á se o agente agiu com dolo ou culpa, o que só é possível na persecução do elemento interno, ausente no direito para Kant. [...] A tese da independência fundamentada na conformação entre ação e dever também padece [...] de falhas. A principal delas seria a falta de clareza em sua aplicação. Isso porque o conceito de lei jurídica como aquela que está conforme ao dever subsume o conceito de lei ética como aquela que é efetuada pelo respeito ao dever. Ora, a ação ética, aquela efetuada quando se cumpre o dever pelo respeito intrínseco ao dever (ação desinteressada) não deixa de ser, ela também, conforme ao dever. A conformação ao dever, aqui, seria comum tanto ao agir desinteressado ("dever pelo dever") como ao agir interessado ("de acordo com o dever'). Ainda, seria um erro pressupor que o cumprimento de uma obrigação jurídica é sempre interessado (não é, como provam as 'obrigações naturais') (WEBER; HAEBERLIN, 2012, p. 132-3). O exemplo da equidade, tratado por Kant, é um direito que está além do direito, ou seja, é um direito com conteúdo ético. Kant diferencia o direito estrito, que não tem nada de ético, do direito lato, que se mescla com o ético. "Contudo, [...] percebendo que a conceituação da equidade como direito [...] aguaria de alguma forma a 'tese da independência', Kant diz que o direito lato não adentra nos domínios da ética" (WEBER; HAEBERLIN, 2012, p. 134). Defende-se, nesta tese, que a "tese da independência" entre ética e direito tem problemas, pois tem falhas em sua fundamentação. $\mathrm{O}$ direito, desvinculado do justo e do ético não tem sentido. "Aristóteles, primeiro a

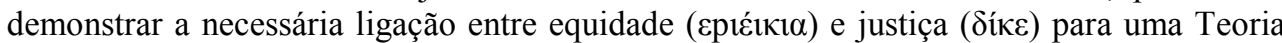
da Justiça bem formatada, na famosa frase de sua Ética: 'A justiça e a equidade são portanto a mesma coisa, embora a equidade seja melhor'. Também, poderíamos citar a lapidar afirmação de Hegel: 'La equidad significa una ruptura del derecho formal por razones morales u otros motivos y se refiere ante todo al contenido de la disputa legal'. $\mathrm{Ou}$, ainda, Chaïm Perelman, quando afirmou: 'Serve-se da equidade como muleta da justiça"' (WEBER; HAEBERLIN, 2012, p. 136). 
O servo não pode apelar ao direito de equidade, pois esse direito é "uma divindade muda que não pode ser ouvida" (MS, 2008, p. 80). Somente a forma do contrato, ou seja, o que foi estipulado, pode ser exigido de ser cumprido.

\begin{abstract}
A divisa (dictum) da equidade é: "o direito mais estrito é a maior injustiça (summum ius summa iniuria)". Mas este mal não pode ser remediado por meio do que é estabelecido como direito, embora diga respeito a uma reinvindicação a um direito, pois esta reinvindicação pertence apenas ao tribunal da consciência (forum poli), ao passo que toda questão do que é estabelecido como direito tem que ser apresentada ante o direito civil (forum soli) (MS, 2008, p. 81).
\end{abstract}

Kant reconhece que não aplicar a equidade é uma injustiça. Porém, mesmo reconhecendo isso, ele não defende que a equidade seja cumprida através do direto no sentido estrito. A equidade não passa de um direito presumido no sentido no sentido lato. A justiça, assim, é abstrata e formal. Não há "condições definidas segundo as quais o juiz deveria se manifestar" (GOMES \& MERLE, 2007, p. 140).

Por que Kant, mesmo reconhecendo a equidade como um direito, não garante pelo direito no sentido estrito a sua efetivação? E não efetivando esse direito, por que ele realiza uma fundamentação moral do jurídico? Essas questões norteiam a presente tese. Através delas, será defendido o pensamento de Hegel e a superação da justiça formal por meio do direito de emergência, por exemplo.

A equidade é a justiça que vai além do formalismo jurídico. É "aquela justiça que nasce não da adequação rígida a uma lei geral e abstrata, mas da adequação à natureza mesma do caso particular, que apresenta algumas peculiaridades com relação a circunstâncias de tempo, de lugar [...]" (BOBBIO, 1991, p. 79). Em alguns casos, a lei aplicada não é equânime. Kant prioriza a lei aplicada e não a equidade. "Kant não admite um tribunal de equidade, ou seja, um tribunal que julgue não com base nas leis gerais e abstratas, mas caso por caso" (BOBBIO, 1991, p. 80).

Para Aristóteles, o justo e o equitativo são a mesma coisa. Porém, em relação ao justo formulado em leis - e não ao justo em si -, o equitativo é superior, pois em virtude de sua universalidade, ele está sujeito ao erro. A equidade é uma correção da justiça legal. Kant considerava, todavia, que a equidade não se prestasse a uma autêntica reinvindicação jurídica e que, portanto, coubesse não aos tribunais, mas ao tribunal da consciência.

A equidade não tem as características da conceituação do direito kantiano, a saber, a coexistência de arbítrios e a faculdade de obrigar. Não tendo coerção, a equidade não é um direito. Isso é um paradoxo. Por que Kant não resolve o problema do direito da equidade a partir da fundamentação moral do direito? Por isso, Kant aborda o direito no sentido 
estrito e o direito no sentido lato. Enquanto o primeiro tem como característica a faculdade de obrigar, o segundo não a tem. Assim, a equidade e o direito de necessidade são direitos equívocos, pois não tem como característica a coerção. Kant considera esses dois direitos como direitos, mas pela conceituação do jurídico do filósofo de Königsberg, eles não poderiam ser considerados direitos. Portanto, são direitos que não são direitos. Esse é o problema encontrado na filosofia kantiana.

Outro direito no sentido lato exemplificado por Kant é o direito de necessidade (ius necessitatis) ${ }^{5}$. Nesse direito, há uma "coerção sem um direito" (Zwang ohne Recht) (MS, 2008, p. 80), ou seja, há uma exigência, mas não há um direito. "Supõe-se que este pretenso direito seja uma autorização a tirar a vida de outrem que nada faz para causar-me dano, quando corro o risco de perder minha própria vida" (MS, 2008, p. 81).

${ }^{5} \mathrm{Na}$ obra $O$ caso dos exploradores de caverna, Lon. F. Fuller trata do estado de necessidade. Nela, o autor apresenta a visão jusnaturalista (através do juiz Foster) e a visão juspositivista (através do juiz Keen) sobre a história de cinco membros de uma sociedade espeleológica que entraram em uma caverna e acabaram soterrados. As vítimas conseguem entrar em contato com as equipes de resgate que estão do lado de fora da caverna através de um rádio. Depois de vinte dias são informados de que o resgate irá demorar e, portanto, eles podem morrer de fome. Um dos exploradores, Whetmore, convence os outros de que um deve ser sacrificado para servir de comida aos outros e propõe um sorteio para escolher o sacrificado. Whetmore acaba sendo assassinado e comido pelos companheiros. Depois que são resgatados, os quatro sobreviventes vão a julgamento por homicídio. Começa então um debate entre os juízes sobre Direito Natural e Direito Positivo. O juiz Foster (Direito Natural) afirma o seguinte: "Eu acredito que há algo mais do que o destino destes desafortunados exploradores em juízo neste caso: encontra-se em julgamento a própria lei. Se este Tribunal declara que estes homens cometeram um crime, nossa lei será condenada no tribunal do senso comum. [...] Afirmo que o nosso direito positivo, incluindo todas as suas disposições legisladas e todos seus precedentes, é inaplicável a este caso e que este se encontra regido pelo que os antigos escritores da Europa e da América chamavam 'a lei da natureza' (direito natural). [...] Concluo, portanto, que no momento em que Whetmore foi morto pelos réus, eles se encontravam não em um 'estado de sociedade civil', mas em um 'estado natural'. [...] A lei que lhes é aplicável não é a nossa, tal como foi sancionada e estabelecida, mas aquela apropriada a sua condição. Não hesito em dizer que segundo este princípio eles não são culpados de qualquer crime" (FULLER, 1976, p. 10-11-14-15). Já o juiz Keen (Direito Positivo) diz: "A questão que desejo deixar de lado diz respeito a decidir se o que estes homens fizeram foi 'justo' ou 'injusto', 'mau' ou 'bom'. Esta é outra questão irrelevante ao cumprimento de minha função, pois, como juiz, jurei aplicar não minhas concepções de moralidade, mas o direito deste país. [...] O texto exato da lei é o seguinte: 'Quem quer que intencionalmente prive a outrem da vida será punido com a morte'. Devo supor que qualquer observador imparcial, que queira extrair destas palavras o seu significado natural, concederá imediatamente que os réus privaram intencionalmente da vida a Whetmore" (FULLER, 1976, p. 41-2). Esse debate é semelhante ao debate desenvolvido entre Kant e Hegel, com algumas diferenças. Tanto Kant quanto o juiz juspositivista Keen afirmam que o papel do juiz é apenas aplicar as leis, as normas jurídicas. Deixam de lado, portanto, tudo aquilo que não está positivado. Não há nada de ético no direito no sentido estrito, destaca Kant. Hegel supera essa visão formal do direito defendendo o direito de emergência, mesmo se esse não fosse positivado. 
Não pode haver lei penal que condene à morte alguém num naufrágio que, a fim de salvar a própria vida, empurra uma outra pessoa, cuja vida está igualmente em risco, para apanhar uma tábua mediante a qual salva a si mesmo, pois a punição com a qual a lei ameaça não poderia ser maior do que a perda de sua própria vida (MS, 2008, p. 81).

Este "pretenso direito" autoriza a violência para salvar a própria vida, para preservar a si mesmo. "O ato de salvar a própria vida por meio de violência não é para ser julgado inculpável (inculpabile) mas apenas impunível (impunibile)" (MS, 2008, p. 81). Assim, há culpa, mas não há punição, pois a necessidade é uma exceção. "A necessidade não tem lei (necessitas non habet legem)" (MS, 2008, p. 82). Portanto, ela pode tudo. Mas, "não poderia haver necessidade alguma que fizesse o que é injusto se conformar à lei” (MS, 2008, p. 82).

Afinal, o injusto, citado por Kant, refere-se ao ato de tirar a vida de outrem para salvar a própria vida ou refere-se à punição de alguém que tirou a vida de outrem para salvar a própria vida? Punir um ato praticado pela necessidade é injusto, mas também não há lei que permita tirar a vida de outrem para se salvar.

A necessidade não precisa de lei. O estado de necessidade é um caso de não-punibilidade. Hoje, no Direito Brasileiro, no estado de necessidade não há nem culpa e nem punição, ou seja, o estado de necessidade não é classificado como um caso de não-punibilidade, mas de não-culpabilidade.

\begin{abstract}
Mas não é justo matar alguém para defender a própria vida? Ou é apenas lícito? Ora, ser lícito não significa ser justo; significa apenas ser autorizado. Talvez a questão devesse ser colocada de outra forma: É lícito (erlaubt) fazer uso de todos os meios disponíveis para a autoproteção? A intenção não é matar, mas a autodefesa, ainda que a consequência seja a morte de alguém. Se lícita é 'uma ação que não é nem ordenada nem proibida', seria ela uma ação 'moralmente indiferente', tendo em vista que não há lei restritiva da liberdade? [...] Parece que Kant não admitiria essa possibilidade (WEBER, 2013, p. 45).
\end{abstract}

A teoria da justiça formal kantiana é insuficiente. Por exemplo, "ao afirmar que a necessidade não pode tornar legal algo injusto, Kant parece não admitir a possibilidade da lei injusta, à qual, portanto, caberia desobediência" (WEBER, 2013, p. 45). Kant, portanto, não aceita a desobediência civil e o direito de resistência.

[...] Eis como o próprio Kant identifica a diferença entre os casos de equidade e estado de necessidade: no primeiro caso, 'o que cada um por si mesmo, com bons motivos, reconhece como justo, pode não encontrar confirmação frente a um tribunal'; no segundo caso, 'o que ele mesmo deve julgar como 
injusto pode obter indulgência e absolvição deste'. A anomalia desses dois casos está portanto no fato de que, enquanto a normalidade da relação entre direito e coação exige que o direito seja satisfeito e o erro remediado, aqui existe de um lado um direito não satisfeito, do outro um erro não remediado. Em outras palavras, seria possível dizer assim: a natureza da justiça implica em que seja dada razão a quem tem razão e negada a quem não a tem. Nos dois casos anômalos, porém, existe esta alteração: no primeiro caso, uma pessoa tem razão e não lhe é dada, no segundo caso, uma pessoa não a tem e lhe é dada (BOBBIO, 1991, p. 81).

As regras devem ser justificadas demonstrando quais são os princípios que as fundamentam. Se, como diz Kant, o justo não pode ser tirado das leis positivas e sim da razão, então, ao tratar da equidade e da necessidade, pode-se sim apelar para as leis morais. Porém, Kant não faz isso e, por isso, ele acaba caindo em um formalismo excessivo. Quando o contrato for injusto, para que aplicá-lo? Kant prende-se ao direito no sentido estrito.

Não é possível separar forma e matéria, senão se cai em uma abstração indeterminada. Nos direitos de equidade e de necessidade deve-se apelar aos princípios e não às leis. A proposta inicial de Kant era fazer uma metafísica do direito. Isso significa dizer que o direito se sustenta na razão. Todavia, Kant não soluciona o problema desses dois direitos.

Por que aplicar leis injustas? Justamente são os hard cases que precisam que se aplique a equidade. Kant não resolve o problema da equidade e da necessidade; ele oferece uma resposta puramente formal. Não se podem minimizar esses dois direitos (como fez Kant), pois são direitos fundamentais. Kant joga esses direitos para o âmbito do direito no sentido lato, pois os considera "duvidosos" (e nas palavras de Bobbio, anômalos).

A distinção entre princípios e regras nos ensina que, quando a aplicação de regras trouxer consequências injustas, deve-se recorrer aos princípios que as fundamentam. Estes não são extralegais, conforme sustenta Dworkin [...]. Assim, o recurso à equidade poderia justificar a não aplicação de uma lei com consequências injustas, ainda que seja um caso de direito duvidoso. Perelman escreve com acerto: 'Desejamos, de fato, que o ato justo não se defina simplesmente pela aplicação correta de uma regra, seja ela qual for, mas pela aplicação de uma regra justa' [...]. Kant reconhece o direito de equidade, mas não o contempla na efetivação do direito estrito. Diz claramente que 'o juiz não pode sentenciar de acordo com condições indeterminadas' [...]. Logo, o juiz, no caso da equidade, não pode fazer justiça. Ele decide de acordo com a lei que, nesse caso, tem consequências injustas. Por que então falar em direito à equidade, já que não tem eficácia? Se pelo direito estrito não se pode assegurar o direito à equidade, uma vez que pertence ao direito em sentido amplo, dever-se-ia fazê- 
lo pelos princípios morais, já que fundamentam as leis jurídicas (WEBER, 2013, p. 44).

O conceito do justo não pode ser tirado da lei positiva, mas somente das leis naturais, dos princípios. O juiz deveria sim buscar nos princípios naturais a aplicação do direito de equidade. Senão, se estaria considerando justa a aplicação de uma lei positiva que carrega em si consequências injustas. Nesse caso, deve-se abandonar a lei e recorrer aos princípios. Segundo uma leitura hegeliana, é possível afirmar que o problema enfrentado aqui resume-se na concepção formal, abstrata e apriorística da justiça e do direito.

\begin{abstract}
Vê-se que ambas as avaliações do que é direito (em termos de um direito de equidade e um direito de necessidade), a equivocidade ou ambiguidade (aequivocatio) nasce do confundir a base objetiva com a subjetiva de exercer o direito (perante a razão e perante o tribunal). O que alguém por si mesmo reconhece com bons fundamentos como direito não será confirmado por uma corte e o que ele deve necessariamente julgar como sendo por si não direito é tratado com indulgência por uma corte, pois o conceito de direito nesses dois casos não é tomado no mesmo sentido (MS, 2008, p. 82).
\end{abstract}

Ou seja, o tribunal pode não confirmar o justo e o culpado pode ser absorvido. Assim, Kant, mesmo em relação aos direitos previstos no sentido no sentido lato, como a equidade e o direito da necessidade, permanece preso ao formalismo. Só é permitido fazer o que o direito positivo prevê, o que a lei prevê, não importando se a ação foi justa ou injusta. Isso é um problema grave que surge em concepções formais do direito.

Hegel, através da eticidade, supera isso. Ele defende o "direito de dizer não" como instância mediadora das determinações ético-políticas. Isso já demonstra a superação do formalismo jurídico proposto por Kant e defendido por algumas correntes juspositivistas do séc. XX.

Ora, tais atos não são passíveis de culpa, muito menos de punição. Não se deveria, nesses casos, recorrer aos princípios, tendo em vista as consequências injustas da aplicação da regra do direito positivo? Embora se possa sustentar um conceito moral do direito, [...] o filósofo de Königsberg parece dar, nos casos de equidade e necessidade, margem à interpretação de uma independência entre moral e direito e, assim, ficar preso ao formalismo jurídico, isto é, a doutrina pura do direito. É curioso que Kant faça a distinção entre direito estrito e direito em sentido lato, onde trata da equidade e do direito de necessidade (casos de direito duvidoso), e apresente uma solução para esses casos a partir do direito estrito (positivo formal). Por que, então, falar em direito em sentido lato? Não se trata de direitos duvidosos. Tanto o direito da equidade 
quanto o da necessidade são direitos líquidos e certos, ainda que em situação concretas nem sempre seja fácil qualifica-los como tais (WEBER, 2013, p. 46).

Nem mesmo o direito no sentido lato resolve o problema da injustiça. A justiça formal é insuficiente. Por que Kant não recorre ao direito natural, já que ele prevê isso, para resolver o problema dos "direitos duvidosos"? Não recorrendo, ele acaba sendo incoerente. Perelman é claro ao afirmar que "a equidade pode prevalecer sobre a segurança, e o desejo de evitar consequências iníquas pode levar o juiz a dar nova interpretação da lei, a modificar as condições de sua aplicação" (2005, p. 166). O direito de necessidade é um direito de exceções. Em determinados casos extremos, é possível não cumprir a lei. Isso é semelhante ao caso do sujeito que mente para salvar a vida de um inocente. Porém, Kant diz que há culpa no estado de necessidade, mas não punição. Isso demonstra que ele permanece preso a concepção formal e abstrata de justiça.

Não somente quando Kant analisa os direitos de equidade e o direito de necessidade, a partir de uma teoria da justiça formal, se cai em uma indeterminação abstrata, mas também quando se investiga sobre o "direito de mentir". A proteção da vida de um inocente não justifica uma mentira? Kant jamais defenderia a mentira, independente das circunstâncias, pois isso seria destruir a dignidade do ser humano.

Suponha que fosse necessário mentir para salvar a vida de uma pessoa. Deveríamos mentir? Kant nos daria a seguinte razão: (1) Devemos executar apenas aquelas ações que se adaptam às regras que poderíamos adotar universalmente; (2) $\mathrm{Se}$ tivéssemos de mentir, estaríamos seguindo a regra 'é permitido mentir'; (3) Essa regra não poderia ser adotada universalmente, porque ela seria auto-refutável: as pessoas parariam de acreditar uma nas outras e, portanto, não trariam bem algum mentir; (4) Então, não deveríamos mentir (RACHELS, 2006, p. $125)$.

Kant, no artigo Sobre o suposto direito de mentir por amor à humanidade, de 1797, trata da história de um homem que é levado a entregar o seu amigo inocente a um assassino por não poder mentir, ressalta que dizer a verdade é um dever, um princípio. Mas este dever vale aprioristicamente ou dentro de determinadas circunstâncias? Se ele vale de forma a priori, Kant acaba caindo no formalismo; mas se ele não vale de forma a priori, devem-se investigar quais são as circunstancias. Kant diz que ele vale aprioristicamente. Portanto, a veracidade é um dever formal. A matéria é irrelevante. Abrir uma exceção significa inutilizar o princípio.

Para salvar o princípio, Kant acaba caindo em um puro formalismo. A veracidade nas declarações é o dever formal do homem em relação a quem quer que seja, por maior que seja a desvantagem que daí decorre para 
ele ou para outrem. Juridicamente, o mentiroso é responsável pelas consequências de sua mentira. Se mentir, abrindo uma exceção, as declarações em geral não tem critério algum e, por conseguinte, também todos os direitos fundados em contratos perdem a sua força; isso é uma injustiça causada à humanidade em geral (cf. KANT, 1988, p. 174-5). Portanto, o pensamento de Kant acerca do "direito de mentir" é o seguinte:

Somos tentados a fazer exceções à regra contra mentir porque, em alguns casos, acreditamos que as consequências da honestidade seriam ruins e as consequências da mentira, boas. Contudo, nunca podemos estar certos sobre como as consequências das nossas ações serão - não podemos saber se implicarão bons resultados. Os resultados de mentir podem ser inesperadamente ruins. Assim, a melhor política é evitar o mal já conhecido, a mentira, e deixar as consequências acontecerem à sua forma. Mesmo se elas forem ruins, não serão nossa culpa, pois teremos cumprido com a nossa obrigação (RACHELS, 2006, p. 127).

Assim como seremos responsáveis por qualquer má consequência de nossas mentiras, também seremos responsáveis por qualquer má consequência de nossas verdades. "Suponha que o assassino ache a vítima e a mate, como resultado de dizermos a verdade. Kant parece entender que seríamos inocentes" (RACHELS, 2006, p. 127). Esse é mais um exemplo de Kant que justifica esta tese: ir para além da justiça formal.

Höffe destaca que Kant não pode ser acusado de formular um "rigorismo moral" e, portanto, há situações (choque de princípios ${ }^{6}$ ) em que é possível justificar a mentira para um bem maior, como para salvar a vida de um inocente.

Visto que o imperativo categórico contém a forma estrita da universalização, recriminou-se Kant de rigorismo moral, de acordo com o qual máximas como não mentir devem ser seguidas em todas as situações. Na verdade, Kant, na famosa disputa com o escritor e político francês Benjamin Constant,

\footnotetext{
6 "Durante a Segunda Guerra Mundial, os pescadores holandeses contrabandearam os refugiados judeus para a Inglaterra em seus barcos, os quais algumas vezes eram parados pelo barco da patrulha nazista. $\mathrm{O}$ capitão nazista gritava e perguntava ao capitão holandês para onde iria, quem estava a bordo etc. O pescador mentia e era liberado para continuar. É claro que o pescador tinha apenas duas alternativas, mentir ou permitir que seus passageiros (e ele próprio) fossem capturados e mortos. [...] Suponha que há duas regras 'É errado mentir' e 'É errado facilitar o assassinato de pessoas inocentes' sejam ambas tomadas como absolutas. O pescador holandês teria de fazer uma dessas duas coisas, portanto uma visão moral que absolutamente as proíbem é incoerente. É claro que essa dificuldade poderia ser evitada se alguém sustentasse que pelo menos uma dessas regras não é absoluta. Mas é duvidoso que essa saída esteja disponível a todo conflito que houver. Também é difícil entender, no nível mais baixo, os motivos pelos quais algumas regras morais devem ser absolutas, se outras não são" (RACHELS, 2006, p. 128-9).
} 


\begin{abstract}
afirmou que não se tem o direito de mentir mesmo contra aqueles que perseguem injustamente alguém [...]. Apesar disso, Kant não defende aqui nenhum rigorismo problemático. [...] Constant afirma que este caso mostra que uma validade incondicionada do dever de veracidade torna toda sociedade impossível. De acordo com Kant, é certo o exato oposto: é a pretensão do direito à mentira que torna toda sociedade impossível. Pois a veracidade é o fundamento de todos os contratos; contratos tornam-se sem sentido se estão sob a ressalva de que os parceiros de contrato fazem uso de seu 'direito de mentir'. (HÖFFE, 2005, p. 213-4).
\end{abstract}

Marcus G. Singer diz que "se alguém tem a intenção de tomar para si determinada máxima [...], para alcançar determinado fim, então já temos um princípio determinado, algo que já contém um conteúdo, a que o imperativo categórico pode ser aplicado" (1975, p. 291). Assim, segundo Singer, a crítica de Hegel a Kant é simplista, pois não há uma pura indeterminação no imperativo categórico, "pois o conteúdo de dever seria determinado pelas máximas" (RAUBER, 1999, p. 42). A determinação do conteúdo é essencial em Hegel e isso ocorre apenas através da mediação social através da família, da sociedade civil e do Estado. Somente a partir das instituições sociais é que ocorre o universal concreto. Kant permaneceu no universal abstrato. Portanto, a crítica de Hegel a Kant não é simplista.

\title{
Considerações finais
}

O justo é definido a partir de quê? Há um critério para isso? Ele tem relação com o direito? E o Direito Positivo tem relação com o Direito Natural? Essas questões foram investigadas por Kant, na obra A Metafísica dos Costumes e por Hegel, na obra Princípios da Filosofia do Direito. Os conceitos direito e justiça são centrais para a presente tese. O direito está vinculado à justiça e, portanto, o justo deve nortear as normas jurídicas. Isso somente é possível por meio de uma superação da concepção da justiça formal.

A Metafísica dos Costumes trata da "Doutrina do Direito" e da "Doutrina da Virtude". A "Doutrina do Direito", intitulada "Princípios Metafísicos da Doutrina do Direito", primeira parte da obra, centra-se no estudo do jurídico. Kant não irá investigar o Direito Positivo, mas o Direito Natural, que contém princípios metafísicos e que dão suporte principiológico a priori ao direito posto pelo homem. A origem desses princípios, por serem a priori, é a razão. Enquanto o direito positivo trata do lícito e do ilícito, o direito natural trata do justo e do injusto. Esse é o papel da metafísica do direito.

A grande questão acerca desses dois "direitos duvidosos" é a seguinte: qual é a relação entre moral e direito? A equidade e o direito de necessidade são dois direitos que não podem se efetivar, pois o juiz não 
pode atendê-los. Esse é o formalismo. O juiz não tem como atender o direito de equidade, pois nada está previsto sobre isso no contrato. O direito, assim, não tem relação com a justiça, mas somente com a lei e com os contratos que deverão ser cumpridos.

\section{Referências bibliográficas}

BOBBIO, Norberto. Direito e Estado no pensamento de Emanuel Kant. Trad. de Alfredo Fait. Brasília: Edunb, 1991.

. "O modelo jusnaturalista". In: BOBBIO, N.; BOVERO, M.

Sociedade e Estado na filosofia política moderna. 2. ed. São Paulo: Editora Brasiliense, 1987.

FULLER, L. L. O caso dos exploradores de caverna. Porto Alegre, Fabris, 1976.

GOMES, A.; MERLE, J. C. A Moral e o Direito em Kant. Belo Horizonte: Mandamentos Editora, 2007.

HECK, J. N. "Contratualismo e sumo bem político". In: Veritas. v.49, n.1, 2004, p.71-92.

HÖFFE, O. Immanuel Kant. Trad. Christian Viktor Hamm, Valério Rohden. São Paulo: Martins Fontes, 2005.

KANT, I. A metafísica dos costumes. Trad. De Edson Bini. São Paulo: EDIPRO, 2008.

1991. Antropologia. Em sentido pragmático. Madrid: Alianza Editorial,

A paz perpétua e outros opúsculos. Lisboa: Edições 70, 1988.

Crítica da Razão Prática. Trad. Valério Rohden. São Paulo:

Editora WMF Martins Fontes, 2011.

PERELMAN, C. Ética e Direito. São Paulo: Martins Fontes, 2005.

RACHELS, J. Os Elementos da Filosofia da Moral. São Paulo: Manole, 2006.

RAWLS, J. História da filosofia moral. São Paulo: Martins Fontes, 2005.

RAUBER, J. O problema da universalização em ética. Porto Alegre: EDIPUCRS, 1999.

SCRUTON, R. "Contract, Consent and Exploitation: Kantian Themes". In:

WILliAMS, H. L (Ed.). Essays on Kant's Political Philosophy. Chicago: University of Chicago Press, 1992. p.213-227.

SINGER, Marcus George. Verallgemeinerung in der Ethik: zur Logik moralischen Argumentierens. Frankfurt: Suhrkamp, 1975.

WEBER, T; HAEBERLIN, P. Equidade na Doutrina do Direito de Kant, Revista Veritas, Porto Alegre, v. 57, n. 3, set./dez. 2012, p. 121-137.

WEBER, Thadeu. Direito e justiça em Kant, Revista de Estudos Constitucionais, Hemenêutica e Teoria do Direito (RECHTD), 5(1): 38-47 janeiro-junho 2013. 
. Ética e filosofia política: Hegel e o formalismo kantiano. Porto Alegre: EDIPUCRS, 2009.

WEINRIB, E. J. "Law as Idea of Reason". In: WILLIAMS, H. L (Ed.). Essays on Kant's Political Philosophy. Chicago: University of Chicago Press, 1992. p. 15-49.

VASCONCELOS, A. "Coação". In: Dicionário de Teoria e Filosofia do Direito. Travessoni, A. (Org.). São Paulo: LTr, 2011. 